\title{
The benefits and challenges of developing and implementing an environmental management system using a participatory approach: a case study of Manchester Metropolitan University, UK
}

\author{
Helena Tinker*1, Dr Konstantinos Tzoulas ${ }^{2}$
}

(1) Environment Team, Manchester Metropolitan University, Cavendish North Building, Cavendish Street, Manchester, M15 6BG, UK

(2) School of Science and the Environment, Manchester Metropolitan University, John Dalton Building, Chester Street, Manchester, M1 5GD, UK

(*) Corresponding author; Email: h.tinker@mmu.ac.uk

Keywords Environmental aspects, ISO 14001, Stakeholder engagement, Teaching, Research, Higher education

\begin{abstract}
Participatory approaches to developing and implementing environmental management in universities could be central in the successful integration of indirect aspects such as teaching and research. The aim of this research was to develop additional insights into the benefits and challenges associated with a participatory approach to environmental management. The objective was to undertake a case study of the participatory approach to environmental management followed by Manchester Metropolitan University, UK. The approach reported here comprised four stages: (a) an environmental review; (b) a stakeholder analysis, (c) participatory meetings and workshops, and (d) synthesis. The outcomes of this approach were a comprehensive management system covering twelve environmental aspects, including teaching and research; a management group chaired by a lead stakeholder for each aspect; a high level environmental strategy board; and university wide networks in facilitating collaboration in sustainability teaching and research. Benefits of increased capacity and reduced conflict were greater than the effort required for overcoming challenges such as securing commitment from and providing support to stakeholders. This chapter will be useful to universities planning to implement ISO 14001 and/ or those that already have an environmental management system and are wishing to expand the scope to include teaching and research.
\end{abstract}

\section{Introduction}

Universities and colleges across the world are increasingly implementing environmental management systems (Clarke and Kouri, 2009; Disterheft et al., 2012; Noeke, 2000). The two best known formally certified systems are the international ISO 14001 standard and the European Eco Management and Audit Scheme (EMAS; (Disterheft et al., 2012).

Implementing the ISO 14001 standard or EMAS requires organisations to identify the environmental aspects and impacts of their activities, products and services within a defined scope of their environmental management system (British Standards Institution, 2004; EC, 2009). Environmental aspects are the organisation's activities, products or services that can interact with the environment, and impacts are any consequent changes to the environment whether adverse or beneficial, wholly or partially resulting from any environmental aspect (EC, 2009; British Standards Institution, 2004). Universities can have direct and indirect environmental aspects (Sammalisto and Brorson, 2006). Direct environmental aspects are associated with activities, products and services for which universities have direct management control (EC, 2009). Direct aspects often include waste generation, emissions and discharges to air, water and land (Clarke and Kouri, 2009). Indirect environmental aspects result from the interaction of an organisation with third parties (EC, 2009). For 
universities indirect environmental aspects include investment practices and purchasing of products, goods and services (Clake and Kouri, 2009), as well as increasing knowledge capital through teaching and research activities (Von Oelreich, 2004). Some authors have argued that because teaching and research activities are some of the largest indirect environmental aspects of universities they ought to be integrated in their environmental management systems (Clarke and Kouri, 2009; Sammalisto and Brorson, 2006; Simkins and Nolan, 2004). However, the scope of environmental aspects that are covered in relevant management systems of universities varies significantly (Disterheft et al., 2012; Clarke and Kouri, 2009; Sammalisto and Brorson 2006; Sammalisto and Arvidsson, 2005; Simkins and Nolan, 2004) and tends to overlook the indirect aspects of teaching and research (Disterfelt et al., 2012; Clarke and Kouri, 2009). Moreover, even when universities are including teaching and research in their environmental management system they may not be taking the practical steps for full integration into core business practices (Sammalisto and Arvidsson, 2005). The drivers and barriers briefly outlined below may help explain the reluctance of universities to fully integrate teaching and research in their environmental management systems.

Bennett and James (1999) suggested that environmental management systems in universities may evolve over three stages, each with different drivers for change. First, driven mainly by cost reduction and legal compliance considerations, universities may focus on operations and direct environmental aspects. Second, driven by the needs for stakeholder management, universities may start considering indirect aspects such as procurement or investments. Finally, factors such as stakeholder partnerships, lifecycle management and contributing to sustainable development drive universities to include teaching and research in their environmental management systems. Moreover, Alshuwaikhat and Abubakar (2008) outlined a list of fifteen international declarations that create a policy framework for universities to integrate teaching, research and campus operations in their contributions to sustainable development (e.g. Kyoto declaration, 1993; Copernicus charter, 2005). However, international declarations may not apply to all universities and institutions may not consider them as operational priorities. Therefore, the drivers for universities to include teaching and research in their environmental management system are voluntary.

There are two initial barriers in integrating teaching and research in the environmental management systems of universities. First, environmental management of universities is usually coordinated by estates or facilities departments (Simkins and Nolan, 2004), which may not be communicating with academic departments or research institutes. Second, environmental management coordinators in these departments may not have the necessary skills to engage with lecturers and researchers (Sammalisto and Brorson, 2006). These barriers make it challenging for estates or facilities departments to instigate, drive and manage actions concerning teaching and research (Sammalisto and Brorson, 2006). However, evidence suggests that barriers to integrating teaching and research can be overcome by using a participatory approach to developing and implementing environmental management systems in universities (Disterheft at al. 2012; Disterheft et al., 2014).

Disterheft et al., (2012) defined participatory approaches, in the context of universities, as the involvement of academic and support staff as well as students in institutional change processes. In their study of environmental management systems across forty seven European universities Distereft et al (2012) found that sixty percent followed participatory approaches ranging from simple information sharing (low participation) to joint projects and collaborative visioning workshops aimed at empowering and building the capacity of stakeholders to take ownership of the required changes (high participation). Furthermore, they found that universities implementing the EMAS were more likely to follow a high participation approach than those implementing ISO14001 (Disterheft at al., 2012). These findings suggest that the guideline requirements of different standards most 
probably influence the approach to environmental management that a university may take. However, the potential benefits and challenges of participation could also be important factors in determining environmental management approaches (Disterheft et al., 2014; Disterheft at al. 2012; Collins et al., 2005). Further understanding is needed of the potential benefits and challenges of participation. The aim of the research presented in this chapter was to develop additional insights into the benefits and challenges associated with a participatory approach to environmental management. The objective was to undertake a case study of the participatory approach to environmental management followed by Manchester Metropolitan University, UK.

\section{Methods}

Two reasons make Manchester Metropolitan University a case study that merits investigation. First, it achieved first position in the UK's People and Planet Green League Table in 2013. This is a system that ranks universities in the UK according to thirteen criteria (e.g. waste, energy, teaching, engagement and investment; People and Planet, 2013). Second, Manchester Metropolitan University is working towards certification to the ISO 14001 standard and is using a bottom-up participatory approach to integrating teaching and research within its environmental management system. This makes Manchester Metropolitan University an unusual case study because European universities implementing ISO14001 are mostly characterised by top-down approaches and limited participation (Disterheft at al., 2012).

\section{Environmental review}

Environmental management starts with a review of the organisation's activities, products and services to identify which significant environmental aspects to include in the scope of its system (Simkins and Nolan, 2004). The review was undertaken by the environment team at Manchester Metropolitan University, which was positioned within the operations department. The environmental review comprised audits of the university's activities, products and services and the associated environmental aspects (direct and indirect). The significance of each environmental aspect was then scored against three criteria i.e. whether the aspect (a) was associated with a legal obligation or existing voluntary commitment (if yes it scored fifteen points; if no it scored zero points); (b) presented a concern to the university or its stakeholders (if yes it scored ten points; if no it scored zero points); and (c) it's impact was estimated to being minimal (scored one point), minor (scored two points), moderate (scored three points) or major (scored four points). Significant aspects were defined as those scoring a minimum of three points (i.e. moderate impact, not related to a commitment or concern). The environmental review revealed twelve significant direct and indirect environmental aspects, which were then grouped into four themes reflecting the common functions of universities i.e. operations, administration, community and academic (the latter including teaching and research; Cortese, 2003).

\section{Stakeholder analysis}

For each environmental aspect a lead stakeholder was identified. Lead stakeholders had to meet at least two of three requirements i.e. have (a) good knowledge of, (b) strategic influence; or (c) top management responsibilities for, each particular environmental aspect. Potential lead stakeholders were identified by the environment team through a review of the roles and responsibilities of posts relevant to each environmental aspect. Once potential lead stakeholders were identified informal one to one meetings with the environment team were arranged to ensure their commitment and to help them build the business case for managing the relevant environment aspect. 


\section{Participation}

Having secured commitment, formal one to one meetings were held between the environment team and each lead stakeholder. These meetings were designed to allow lead stakeholder to (a) develop ownership of, and (b) take responsibility for, the strategic direction and management of the environmental aspect(s) that they were concerned with. Each lead stakeholder was then asked to form a management group to develop the action plans and procedures for managing their environmental aspect(s). Stakeholders who were invited to join the management groups were identified by a snowball approach (i.e. first stakeholder identified the first group of other stakeholders, who then identified the second group and so on). In order to join a management group additional stakeholders had to meet two requirements i.e. (a) have knowledge of the particular environmental aspect, and (b) be involved in some part of its management. This way management group members as well as relevant consultees were identified from across the university.

In addition to the management groups two informal university wide networks were established by the relevant lead stakeholders and with support from the environment team. A sustainability research network was established to facilitate academic collaboration; and a sustainability teaching group to develop support tools and programmes for embedding sustainable development in curricula. The former involved researchers across the university and the latter academics from relevant departments of the university (business school, school of science and the environment, centre of excellence in teaching and learning). Top management commitment was secured through the establishment of an environmental strategy board comprising managers across the university with significance influence or control of relevant budgets. The environment team with help from the director of finance identified these managers, engaged them to secure their commitment and to develop a proposal to the university's executive for the establishment of the environmental strategy board. Recognising the requirements of senior management commitment for ISO 14001 the university's executive approved the establishment the board.

\section{Synthesis of university's environmental management system}

Each management group met individually and discussed and finalised its own terms of reference, objectives, targets, key performance indicators, registers of specific aspects and impacts and of legal compliance, and action plans. These contributions from each management group were then collected and synthesized by the environment team. The objectives, targets and key performance indicators were collated in a draft environmental strategy. The remaining documents formed the records for policy commitments and performance monitoring. The draft environmental strategy was finalised and agreed through a collaborative two hour workshop involving the environment team and all lead stakeholders. The final strategy was presented to and approved by the executive of the university. Finally, the environment team compiled the environmental aspects, policy commitments, strategy and performance monitoring records into the university's environmental management system.

\section{Findings: environmental aspects}

With the exceptions of biodiversity (Wright and Wilton, 2012) and teaching and research (Disterfelt et al., 2012; Clarke, 2006) that are often not included in the scope, all remaining environmental aspects identified by the review are commonly addressed in the environmental management of universities (Table 1; Disterheft et al., 2012; Clarke and Kouri, 2009;

Sammalisto and Brorson 2006; Sammalisto and Arvidsson, 2005; Simkins and Nolan, 2004). Four of the twelve environmental aspects were indirect, and the environment team had little or no control over these. These indirect aspects were procurement, teaching, research and engagement (Table 1). 
Table 1: Direct and indirect environmental aspects

\begin{tabular}{|c|c|c|}
\hline Environmental aspects & Direct & Indirect \\
\hline Energy management ${ }^{1}$ & $\bullet$ & \\
\hline Emissions and discharges ${ }^{1 *}$ & $\bullet$ & \\
\hline Water management ${ }^{1}$ & • & \\
\hline Waste management ${ }^{1}$ & - & \\
\hline Transport management ${ }^{1}$ & $\bullet$ & \\
\hline Capital programmes ${ }^{1 * *}$ & $\bullet$ & \\
\hline Buildings maintenance $^{1}$ & $\bullet$ & \\
\hline Biodiversity management $^{1}$ & • & \\
\hline Sustainable procurement ${ }^{2}$ & & • \\
\hline Teaching sustainability ${ }^{3}$ & & $\bullet$ \\
\hline Sustainability research ${ }^{3}$ & & $\bullet$ \\
\hline Engagement $4 * * *$ & & $\bullet$ \\
\hline
\end{tabular}

Themes: 1: Operations; 2: Administrative; 3: Academic; 4: Community; Notes: $\left({ }^{*}\right)$ includes to land, water and air; $(* *)$ includes contract specification and management; $(* * *)$ includes staff, students and neighbouring communities and is a cross cutting activity

\section{Lead stakeholders}

Nine of the twelve lead stakeholders were identified within operational departments of the university and three from the academic community (Table 2). The deputy vice chancellor (student success) and the head of research (academic post at professorial level) were recognised as lead stakeholders for teaching and research respectively. At senior management level there was a lack of expertise in urban biodiversity, and consequently for this activity an academic with the appropriate research expertise was selected as the lead stakeholder. The remaining key stakeholders included two heads of services (property management and procurement) and three senior managers from the environment team (Table 2). These lead stakeholders, with appropriate support from the environment team, were responsible developing the environmental management system for their respective environmental aspect.

Table 2: Lead stakeholders

\begin{tabular}{|c|c|}
\hline Environmental aspect & Lead stakeholder \\
\hline Energy management ${ }^{1}$ & Head of property services \\
\hline Emissions and discharges ${ }^{1 *}$ & Head of property services \\
\hline Water management ${ }^{\mathbf{1}}$ & Head of property services \\
\hline Waste management ${ }^{1}$ & Manager of waste and recycling \\
\hline Transport management $^{\mathbf{1}}$ & Manager of the travel plan \\
\hline Capital programmes $1 * *$ & Head of property services \\
\hline Buildings maintenance ${ }^{1}$ & Head of property services \\
\hline Biodiversity management $^{1}$ & Academic lead (biodiversity and green infrastructure) \\
\hline Sustainable procurement $^{2}$ & Head of procurement \\
\hline Teaching sustainability $^{3}$ & Deputy vice chancellor (for student success) \\
\hline Sustainability research $^{3}$ & Head of research \\
\hline Engagement $4 * * *$ & Manager of sustainability engagement \\
\hline
\end{tabular}

Themes: 1: Operations; 2: Administrative; 3: Academic; 4: Community; Notes: $(*)$ includes to land, water and air; $(* *)$ includes contract specification and management; $(* * *)$ includes staff, students and neighbouring communities and is a cross cutting aspect 


\section{Participation}

Additional stakeholders that were involved in the development of the environmental management system, both as management group members and/ or as consultees on particular aspects, ranged from estates and operation departments, to academic teaching and research departments, and the student union (Table 3). The environmental strategy board comprised representatives from estates and facilities, academic faculties, strategic planning, finance, and student success. The board's responsibilities included providing strategic support for the environmental management system; ensuring its integration with the university's strategic planning processes and core business; and overseeing implementation and reporting progress, opportunities and risks to the university's executive.

Table 3: Additional stakeholders

\begin{tabular}{|l|c|}
\hline Other relevant internal stakeholders & Engaged in theme: \\
\hline Academics teaching relevant subjects across the university & 3 \\
\hline Campus management and estates & 1 \\
\hline Centre for excellence in teaching and learning & 3 \\
\hline Communications and marketing & 4 \\
\hline Continuing professional development & 3 \\
\hline Deans of faculties & 3 \\
\hline Deputy vice chancellor for strategic planning and research & 3 \\
\hline Employability initiatives & 4,3 \\
\hline Health and safety & 1 \\
\hline Human resources & 2 \\
\hline Procurement and finance & 1,2 \\
\hline Key suppliers and contractors & $1,2,3$ \\
\hline Pro vice chancellor for students & 3 \\
\hline Research and knowledge exchange & 3 \\
\hline Research centres and groups & 1,3 \\
\hline Student halls management services & 1 \\
\hline Students & $1,3,4$ \\
\hline Students union & 1,4 \\
\hline Technical services teams (labs, workshops) & 1 \\
\hline Volunteering initiatives & 4 \\
\hline External partners and local community & $1,2,3,4$ \\
\hline Themes: Operations; 2 Administrat $3:$ Academic; & \\
\hline
\end{tabular}

Themes: 1: Operations; 2: Administrative; 3: Academic; 4: Community; Note: for environmental aspects related to each theme refer to Tables 1

\section{The environmental management system}

The university's environmental management system shows the interrelationships between environmental aspects, policy commitments, strategy and performance (Figure 1). For each environmental aspect, there are policy commitments, objectives with targets and key performance indicators, and action plans for delivering improvements. Progress on action plans and the key performance indicators are monitored annually and reported in the annual environmental statement (Figure 1). Performance monitoring and reporting informs the setting of new commitments, objectives and targets (this feedback loop is indicated by the two way arrows on Figure 1). 
Figure 1: The environmental management system

\begin{tabular}{|c|c|c|c|}
\hline $\begin{array}{l}\text { Environmental aspects } \\
\text { Energy management }{ }^{1} \\
\text { Emissions and discharges }^{1 *} \\
\text { Water management }^{1} \\
\text { Waste management }^{1} \\
\text { Transport management }^{1} \\
\text { Capital programmes }^{1 * *} \\
\text { Buildings maintenance } \\
{ }^{1} \\
\text { Biodiversity management } \\
\text { Sustainable procurement }^{2} \\
\text { Teaching sustainability }^{3} \\
\text { Sustainability research } \\
\text { Engagement }^{4} * * *\end{array}$ & $\begin{array}{c}\text { Policy } \\
\text { commitments } \\
\text { for improvement }\end{array}$ & $\begin{array}{l}\text { Objectives } \\
\text { Targets } \\
\text { KPIs } \\
\text { Action Plans }\end{array}$ & $\begin{array}{c}\text { Measured by KPIs } \\
\text { Presented in an } \\
\text { Annual } \\
\text { Environmental } \\
\text { Statement }\end{array}$ \\
\hline
\end{tabular}

Themes: 1: Operations; 2: Administrative; 3: Academic; 4: Community; Notes: $(*)$ includes to land, water and air; $(* *)$ includes contract specification and management; $(* * *)$ includes staff, students and neighbouring communities; (I) each environmental aspect has a number of policy commitments; (II) objectives, targets, key performance indicators (KPIs) and action plans for each environmental aspect form the strategy; (III) performance in achieving the targets is monitored annually through the key performance indicators; arrows indicate that there are two way influences between performance, strategy and commitments

\section{Discussion: the participatory approach}

Engagement of a wide range of stakeholders, commitment from senior management and executives, collaboration and shared ownership of an environmental vision and strategy are critical success factors for participatory processes in environmental management (Disterheft et al., 2014). The outcomes of the environmental review formed the foundation for developing the participatory approach followed by Manchester Metropolitan University. First, the four themes (i.e. operations, administrative, academic and community), in which the environmental aspects were grouped, helped clarify management responsibilities for each aspect. Second, the twelve environmental aspects of the university (i.e. energy, emissions, water, waste, transport, capital programs, buildings, biodiversity, procurement, teaching, research and engagement) determined the stakeholders that were engaged in the next stage of the process. So, the review resulted in a comprehensive description of the institution's functions (themes) and environmental aspects, which in turn informed the identification of all relevant stakeholders.

Two elements at the start of the participation process ensured that lead stakeholders developed ownership of, and took responsibility for, managing their respective environmental aspect(s). First, during the initial formal meetings lead stakeholders were engaged in identifying draft objectives and targets, as well as the priorities relating to managing the environmental aspect(s), which they were concerned with. These draft objectives and targets were developed by reviewing and discussing the environmental review documentation that the environment team had undertaken. This way the stakeholders developed ownership of the relevant environmental aspect(s) from the outset. Second, lead stakeholders were invited to finalise the draft objectives and targets by consulting and engaging appropriate staff, students and/or external organisations as they saw appropriate. This gave lead stakeholders the responsibility for both the strategic direction and management of the environmental aspect (i.e. objectives, targets and operational actions plans) as well as for engaging a wide network of additional stakeholders. Offering to the lead stakeholders ownership of, and responsibility for, managing the university's environmental aspect(s), and providing the necessary support 
from the environment team, ensured that stakeholders were empowered to influence change. This approach was particularly important for including teaching and research in the university's environmental management system because the environment team at the beginning of the process had limited working relationships with the academic community.

The management groups, the university wide research and teaching networks and the environmental strategy board were all established through a bottom-up approach (i.e. key stakeholders involving their networks). This bottom up-approach to engagement and participation was important to ensure that all lead and additional stakeholders across the university had ownership of the relevant environmental aspects. Importantly, the establishment of the environmental strategy board ensured top level commitment and addressed in advance the forthcoming changes to the ISO 14001 standard requiring the involvement of top management and the integration of environmental management into core business processes and strategy (International Standards Organisation, 2013).

\section{The benefits of the participatory approach}

Stakeholder participation in environmental management could bring about a number of benefits associated with inclusive decision-making (Mathur et al, 2008). The participatory approach that Manchester Metropolitan University followed in developing its environmental management system highlighted five benefits. First, stakeholder engagement increased ownership and shared responsibility of the environmental management system, which facilitated policy and strategy development and delivery. Second, since the stakeholders were engaged in producing the environmental management policy commitments, objectives, targets and KPIs there was reduced conflict and resistance when these were implemented. Third, the participatory approach facilitated the inclusion of teaching and research in the scope of the environmental management system. This is because it allowed relevant academic and non-academic stakeholders to come together and discuss shared goals and actions. Moreover, integrating teaching and research in the environmental management system not only contributed to the university's efforts to managing one of its largest indirect aspects (Clarke and Kouri, 2009; Sammalisto and Brorson, 2006); but it also allowed identifying relationships and integrating best practice between operations, academic and support departments. Fourth, collaboration, communication and exchange of information could encourage capacity building amongst a range of stakeholders (Disterheft et al., 2014). Capacity building was demonstrated in the case study reported here by the establishment of the management groups (one for each environmental aspect), the university wide teaching and sustainability networks, and the environmental strategy board. Finally, engaging the commitment of senior management provided opportunities for integrating environmental management into core business processes and strategy.

\section{The challenges of the participatory approach}

Participatory approaches to environmental management present a number of challenges as well as benefits (Disterheft et al., 2014). In particular the Manchester Metropolitan University case study uncovered four important challenges. First, engaging many stakeholders often leads to a slow implementation process due to time required to build new relationships, increase knowledge and skills and discuss and arrive at a consensus (Disterheft et al., 2012, Disterheft et al.2014). This challenge was resolved by anticipating and allowing for time delays during the planning stages of the environmental management system. Moreover, the more established the management groups and processes became, the less the time delays were. The second important challenge was securing ongoing key stakeholder interest and commitment. To overcome this challenge management support was secured at all levels, the core business case for each lead stakeholder was communicated clearly, and they were 
allowed to develop their own achievable and incremental performance objectives and targets. This was especially important for integrating the aspects of teaching and research.

Using quantitative key performance indicators presented a challenge for teaching and research. Quantitative indicators were not seen appropriate because these activities have important qualitative elements. This challenge was addressed by allowing the use of mixed qualitative and quantitative indicators. The final challenge presented by this participatory approach was maintaining momentum and interest amongst stakeholders, who had often competing priorities. To surpass this challenge ongoing, as well as additional ad-hoc, communication and coordination of support from the environment team was provided. It remains important for Manchester Metropolitan University to maintain momentum and build upon the benefits of participation for moving its environmental management system from the implementing to the operating, and checking and correcting levels of the ISO 14001 standard. In particular, ongoing appropriate resources and support (e.g. sustainable development curriculum co-ordinator post) are required to ensure that policy commitments and targets for teaching and research are delivered. The insights developed by the case study reported here will be useful to (a) universities planning to implement ISO 14001 in incremental stages; and/ or (b) universities that already have and environmental management system and are planning to expand the scope to include teaching and research. Additional research is required to explore how universities would have to re-align their environmental management systems to meet the proposed changes to ISO 14001 after 2015.

\section{Conclusion}

The approach that Manchester Metropolitan University followed for its environmental management is characterised by collaboration, shared ownership and empowerment in developing a strategy and system covering both direct and indirect environmental aspects including teaching and research. Teaching and research activities tend to be excluded from the scope of the environmental management system of most universities (Disterfelt et al., 2012; Clarke and Kouri, 2009). This reflects a missed opportunity to develop a holistic approach to environmental management and to focus resources on some of universities' biggest indirect environmental aspects (Clarke and Kouri, 2009; Sammalisto and Brorson, 2006). Integrating teaching and research in a university's environmental management system requires engaging all relevant internal stakeholders in policy and strategy development as well as in delivery and performance monitoring. The participatory approach that was followed by Manchester Metropolitan University increased ownership, captured expertise and enthusiasm, reduced conflict and increased the capacity of stakeholders and relevant staff to deliver environmental improvements. On the other hand, a participatory approach also presented a number of challenges including slowing implementation at the initial stages and needing ongoing and clear communication to secure commitment and maintain momentum. Despite the challenges Manchester Metropolitan University successfully established a new senior level environmental strategy board, university wide sustainability research and teaching networks, and a management framework and strategy with delivery mechanisms led by appropriate stakeholders and management groups. This demonstrates that the benefits of participation were greater than the effort required for overcoming the challenges.

\section{Acknowledgements}

The authors would like to thank Dr John Hindley, head of environmental strategy, Manchester Metropolitan University, UK, for providing resources and support for the case study reported here; Alex Hobbins, EcoCampus, Loreus Ltd, UK, for his insightful advice on implementing environmental management systems at universities; and all lead and additional 
stakeholders from Manchester Metropolitan University, UK, for their contribution to the development of the environmental management system reported here.

\section{References}

Alshuwaikhat, H. M., Abubakar, I., (2008), An integrated approach to achieving campus sustainability: assessment of the current campus environmental management practices, Journal of Cleaner Production16, 1777-1785.

Bennett, M., James, P., (Eds), (1999), Sustainability measures: evaluating and reporting on social and environmental performance, Greenleaf Publishing, Sheffield, UK.

British Standards Institution, (2004), EN ISO 14001:2004 Environmental management systems- requirements with guidance for use, BSI Standards Ltd, s.l.

Clarke, A., Kouri, R., (2009), Choosing an appropriate university or college environmental management system, Journal of Cleaner Production, 17, 971-984.

Clarke, A., (2006), The campus environmental management system cycle in practice: 15 years of environmental management, education and research at Dalhousie University, International Journal of Sustainability in Higher Education, 7, 4, 374-89.

Cortese, A.D., (2003). The critical role of higher education in creating a sustainable future, Planning for Higher Education, 31, 3, 15-22.

Collins, E., Kearins, K., Roper, J., (2005). The risks in relying on stakeholder engagement for the achievement of sustainability. Electron. J. Radic. Organ. Theory 9 (1), 1e19.

Disterheft, A., Caeiro, S., Ramos, M., Rosário, A., Ulisses, M., (2012), Environmental management systems (EMS) implementation processes and practices in European higher education institutions - top-down versus participatory approaches, Journal of Cleaner Production, 31, 80-90.

Disterheft,A.,Caeiro,S.,A.,Ulissess,M.,Leal Filho.,W., (2014), Sustainable Universities- a study of critical success factors for participatory approaches, Journal of Cleaner Production, article in press, http:/dx.doi.org/10.1016/j.jclepro.2014.01.030

EC (2009), Regulation No 1221/2009 on the voluntary participation by organisations in a Community eco-management and audit scheme (EMAS), European Council and European Parliament, Brussels

International Standards Organisation.,(2013), Environmental Management Systems Requirements with guidance for use, Committee Draft - 14001.2, International Standards Organisation, Geneva.

Narain Mathur, V., Price, A.D.F., Austin, S., (2008), Conceptualizing stakeholder engagement in the context of sustainability and its assessment, Construction, management and Economics, 26, 6, 601-609.

Noeke, J., (2000), Environmental management systems for universities: a case study, International Journal of Sustainability in Higher Education, 1, 3, 237-51.

People and Planet, (2013), People \& Planet Green League Guide 2013: Driving UK universities' transition to a fair and sustainable future, People \& Planet, Oxford, UK

Sammalisto, K., Arvidsson, K., (2005), Environmental management in Swedish higher education: Directives, driving forces, hindrances, environmental aspects and environmental co-ordinators in Swedish Universities, International Journal of Higher Education, 6, 1, 18 - 35

Sammalisto, K., Brorson, T., (2006), Training and communication in the implementation of environmental management systems (ISO 14001): a case study at the University of Gavle, Sweden, Journal of Cleaner Production, 16, 3, 299-309.

Simkins, G., Nolan, A., (2004), Environmental management system in universities, Environmental Association for Universities and Colleges (EAUC), s.l. 
Von Oelreich, K., (2004) Environmental certification at Malardalen University, International Journal of Sustainability in Higher Education, 5, 2, 133-146.

Wright, T.S.A.,Wilton, H., (2012), Facilities management directors' conceptualizations of sustainability in higher education, Journal of Cleaner Production, 31, 118-125.

\section{Biographical notes}

Helena Tinker is Environment and Energy Manager at Manchester Metropolitan University, UK. She is leading ISO 14001 implementation at the university. She has implemented EMAS and ISO 14001 in manufacturing companies and local authorities in the UK and has supported a number of local authorities across Europe achieve EMAS.

Dr Konstantinos Tzoulas is Lecturer in Environmental Management at the School of Science and the Environment at Manchester Metropolitan University, UK. His teaching focuses on sustainable development policy and urban and rural ecosystem management. He is the chairman of the university's Biodiversity Management Group.

In Leal Filho, W., et al, (Eds), 2014, Integrating sustainability thinking in science and engineering curricula, Springer, ISBN: 978-3-319-09473-21 